\title{
14. National counter-terrorism responses: India
}

\author{
Anthony Davis
}

\section{POLITICAL AND SECURITY CONTEXT}

\section{Contemporary Terrorism in India}

The challenge of terrorism that has confronted India in the post-independence era has arguably been more complex, sustained and destructive than that faced by any other liberal democratic order in the same period. Reflecting India's size, ethnic and religious diversity, and the perennially toxic nature of south Asian geopolitics, terrorism in some shape or form is less a recent aberration than a constantly mutating norm. The South Asia Terrorism Portal (SATP) has listed some 180 terrorist groups that have operated within India over the last 20 years, many of them co-listed as transnational terror networks operating in or from neighbouring South Asian countries such as Bangladesh, Nepal and Pakistan ('Indian Terrorist, Insurgent and Extremist Groups', 2018).

Terrorism in the contemporary Indian context can be seen as falling into three essentially distinct but occasionally overlapping categories: firstly, terrorism employed by ethno-nationalist movements seeking either greater autonomy or statehood in the federal structure of the Indian Union or complete separation from it; secondly, terrorism used by left-wing extremist movements seeking a fundamental overturning of the nation's capitalist economic order and liberal democracy; and thirdly, terrorism driven by religious ideologies. Most salient among India's religious divides has been that between Hindus and Muslims, that in the wrenching 1947 Partition of British India defined the birth of both modern India as a secular polity and Pakistan as a Muslim homeland. It was a partition that was to leave within India a Muslim minority that today, at 165 million or around 13 per cent of the national population, is among the largest Muslim populations worldwide, after those of Indonesia and Pakistan itself (Rukmini and Singh, 2017).

The trauma first of Partition and then, almost immediately, of war over the disputed state of Jammu and Kashmir, sowed the seeds of an abiding enmity 
between India and Pakistan that to date has provoked three conventional wars and is now overshadowed by a nuclear stand-off. It has been an enmity which has also profoundly influenced the nature and scope of the terrorist threat confronting India. From 1947 onwards, Pakistan has seldom missed an opportunity to use proxy actors to foment or exacerbate religious, social and ethnic divides within its larger, more powerful neighbour. Pakistan's strategy of waging a war of attrition by proxy has blurred the line between terrorism and insurgency to a degree that is unique in the context of liberal democracies. Against this regional backdrop, India has confronted several concerted terrorist campaigns since Independence. Arguably the first of these was the violence associated with the radical communist Naxalite movement of the late 1960s and early 1970s. Following a peasant uprising in Naxalbari in Darjeeling district of West Bengal, terrorist violence spread across West Bengal, the state capital of Kolkata in particular, and north India more broadly (Central Intelligence Agency, 1970).

Since the eruption of the Naxalite movement in the late 1960s, left-wing extremism and its terrorist manifestations have posed an almost continuous internal security challenge to the Indian state. In the 1980s and 1990s, left-wing terror morphed into the threat posed by the Communist Party of India (Marxist-Leninist) People's War, better known as the People's War Group (PWG). Centred in the south-central states of Andhra Pradesh and Maharashtra, PWG violence targeted local police and administration in rural areas as well as state-level politicians (Singh, 1995).

In this century, the 2004 merger of the PWG with the northern-based Maoist Communist Centre of India (MCCI) gave birth to the Communist Party of India (Maoist), or CPI-Maoist, which stepped up its activities across a wide swathe of south-central and northern India. In 2006 it was described by then-Prime Minister Manmohan Singh as 'the single biggest internal security challenge' facing the country (Hindu, 2016). That said, the dogmatically Maoist ideology of the party has dictated a strategy of armed struggle based on rural guerrilla warfare, leading to the creation of 'liberated zones' and a uniformed People's Liberation Guerrilla Army (PLGA). Drawing primarily on a tribal support base in the forests of central India - notably Chhattisgarh, Jharkand and northern Andhra Pradesh states - PLGA guerrillas have occasionally inflicted heavy casualties on police and paramilitary forces. They have also sabotaged railway tracks in several states. On one occasion in 2010, this resulted in the death of 141 passengers in West Bengal, when derailed carriages of a passenger train were hit by a goods train speeding in the opposite direction. However, as a matter of policy the CPI-Maoist has consistently eschewed mass-casualty attacks on civilian targets, and to this extent falls outside the scope of this chapter. 
Naxalite terrorism targeted specifically on individual 'class enemies' and 'anti-people' politicians paled into insignificance when set against the brutal and protracted terrorist campaign waged by the Khalistan movement, centred on Punjab. Between 1981 and 1995, almost 21000 people died in a campaign aimed ostensibly at achieving secession from the Indian Union for an independent Sikh homeland in the northwest, that notionally covered the states of Punjab, Haryana, Himachal Pradesh and parts of Rajasthan with its capital in Chandigarh ('Annual Casualties in Punjab Datasheet', 2018). Simmering violence exploded following the Indian Army's June 1984 assault on militants holed up in the Sikh Golden Temple in Amritsar. Operation Blue Star prompted the assassination of Prime Minister Indira Gandhi in October, which in turn triggered an orgy of anti-Sikh communal rioting and slaughter in the capital, New Delhi. Prosecuted by a clutch of Sikh terrorist groups, the Khalistan campaign degenerated rapidly into essentially nihilistic terrorism, involving repeated and indiscriminate massacres of Hindus on buses and trains in Punjab, along with occasional bombings and assassinations of senior officials and moderate Sikh leaders.

Intimately linked to the Sikh diaspora in North America and Europe, Khalistani terrorism also brought one of the world's first mass-casualty aviation attacks: the June 1985 bombing of Air India Flight 182, a Boeing 747 which was brought down over the Atlantic Ocean with the loss of all 329 lives (Global News, 2020). By the time the Khalistan movement was crushed in an often controversial, police-led campaign of counter-terrorism in the early 1990s, increased arms support from Pakistan to the terrorists had effectively blurred the lines between terrorism and insurgency. For a period, terrorists armed with assault rifles, light machine guns and rocket-propelled grenades effectively outgunned the state police (Gill, 2001). The decline of the Khalistan campaign overlapped with the rekindling of conflict in Kashmir. Against a backdrop of significant popular support from the bitterly disaffected majority Muslim population, the Kashmir revolt aimed at securing either the independence of Kashmir or its accession to Pakistan, and began in 1989. Fanned by generous logistical support from a Pakistani military eager to replicate the success of the anti-Soviet jihad it had supported in Afghanistan, hostilities escalated sharply in the early 1990s and continued for the rest of the decade.

Assuming an increasingly Islamist animus as the result of Pakistani support to jihadist factions, the conflict unfolded as a guerrilla insurgency punctuated by explicitly terrorist massacres targeted against Hindu pilgrims and Sikh communities (Davis, 2000). Between 1989 and the end of 2016 over 44000 had been killed ('Annual Casualties in Jammu and Kashmir Datasheet', 2018). Similarly blurred lines between terrorism and insurgency have characterised ethno-nationalist and tribal conflicts in India's perennially troubled northeast. 
Of the region's seven states, the most volatile in recent decades have been Assam, Nagaland and Manipur. Militant organisations in these states have generally aspired to wage popularly supported guerrilla struggles in pursuit of autonomy or separation from India. Larger factions such as the United Liberation Front of Asom (ULFA) and the National Socialist Council of Nagaland (NSCN) have raised uniformed guerrilla forces and sought to purchase large quantities of weapons on the regional arms market. Predictably, at various times they have also benefited from financial and training support from Pakistan as well as (depending on the government of the day) from Bangladesh (Kiessling, 2016, p. 21).

At the same time, several groups, most notably ULFA and the National Democratic Front of Bodoland (NDFB), a Christian faction active in districts of Assam north of the Brahmaputra River, have staged repeated terrorist bombings and indiscriminate small-arms fire attacks on markets, trains and other civilian targets. In some instances, these have resulted in significant casualty tolls ('National Democratic Front of Bodoland ...', 2018). In contrast to tribal violence in the remote northeast, Islamist terrorism targeted squarely on the cities of the India's heartlands has gained far greater salience both domestically and internationally. And conducted in the shadow of the Subcontinent's nuclear stand-off, it too has tended to blur the line between domestically and internationally driven terrorism; between guerrilla warfare and terrorism; and between conventional and unconventional warfare.

The event that acted as a fateful catalyst in the onset of jihadist terrorism in India owed nothing to Pakistani influence or machination, however. On 6 December 1992, following weeks of mounting tension, a mob of radical Hindu zealots associated with the right-wing Rashtriya Swayamsevak Sangh (RSS) finally demolished the centuries-old Babri Mosque in northern India. Built by the Moghul emperor Aurangzeb, the mosque had earlier, according to the hard-line Hindu narrative, been the site of a temple to the Hindu God Rama. In short, it had become a defining flashpoint for the Subcontinent's primary religious divide, a rift exacerbated by a rising tide of Hindu nationalist populism impacting upon Indian electoral politics. The demolition of the mosque was followed by weeks of murderous communal rioting across northern and central India, with casualties rising to an estimated 9000 dead. The nation's commercial capital of Mumbai bore the brunt of the violence in two distinct waves. Initial rioting by Muslims incensed over the demolition flared immediately in December 1992; then in January 1993 a Hindu backlash against Muslim communities in the city left some 900 Muslims dead (Wilkinson, 2006, p. 14).

The worst communal violence since Independence triggered a terrorist response carried out by Mumbai's Muslim-dominated mafia, specifically the so-called 'D Company' of Daoud Ibrahim Kaskar and his lieutenants. With an intimate knowledge of the city, and benefiting from logistical support extended 
by the Pakistani military's Inter-Services Intelligence Directorate (ISI), D Company operatives were a lethal terrorist force in waiting. On 12 March 1993, 15 bombs exploded across multiple prominent locations in Mumbai. Leaving 257 dead and 713 wounded, this onslaught marked the most lethal coordinated urban terror attack in Indian history up to that date. It also opened the floodgates to two decades of high-casualty urban terror attacks.

A decade after the 1993 Mumbai bombings, an already strained situation was further exacerbated by a similar dynamic involving widespread communal violence triggering a terrorist response. In early 2002, anti-Muslim pogroms swept eastern Gujarat state. They were triggered by a 27 February fire on a train carrying Hindu pilgrims back from Ayodhya, site of the demolished Babri Mosque. Fifty-nine people were burned to death near the town of Godhra, where the train had stopped. Despite the fact that the fire was very likely accidental rather than a 'pre-planned conspiracy' by local Muslims, another wave of anti-Muslim communal rioting erupted across several major urban centres of the state. Senior elements of the state government, run by the Hindu-nationalist Bharatiya Janata Party (BJP), and local police were allegedly complicit in well-organised attacks by Hindu extremists on communities and mosques. According to official figures, this wave of killing resulted in the deaths of 790 Muslims. Clashes also left 254 Hindus dead, with another 2500 people of both faiths injured (BBC, 2005).

The Gujarat pogroms served as the inspirational fuel for yet another wave of terror attacks by young Indian Islamists associated with the Students Islamic Movement of India (SIMI). Proscribed in 2002, SIMI was to morph into the avowedly terrorist Indian Mujahideen (IM). Predictably, logistical, financial and training support was again forthcoming from Pakistan. The most horrific of these attacks was undoubtedly the coordinated wave of bomb attacks on commuter trains in Mumbai on 11 July 2006, which killed 189 and wounded around 700 (Sayed and Hakim, 2016).

A critical component of the threat posed by radicalised Muslim youth associated with SIMI and IM were two Pakistan-based jihadist organisations that had emerged from the insurgencies that wracked Afghanistan and more importantly Kashmir in the 1980s and 1990s: Lashkar-e-Taiba (LeT, or Army of the Pure) and Jaish-e-Mohammed (JeM, or Army of Muhammad). Both groups operated openly in Pakistan, recruiting mainly in Pakistani Punjab for the jihad in Kashmir. The Kashmir conflict, which had flowed almost seamlessly from the anti-Soviet jihad in Afghanistan, reflected the extent to which jihad as one of the five pillars of Islam had become embedded in the ideological underpinnings of the Pakistan Army, while at the same time resonating through wide swathes of conservative Pakistani society beyond. With the tacit support of the military's ISI, both LeT and JeM ran guerrilla training camps in what in India 
is known as Pakistan-occupied Kashmir (POK) and in Pakistan is known as Azad (Free) Kashmir (Tankel, 2011, p. 47).

Of the two, LeT and its civilian wing the Markaz ud Dawah w'al Irshad (the Centre for Proselytising and Guidance, later to be re-branded the Jamaat ud Dawah) has remained the larger and more influential. As an instrument of terrorism in India, the role of LeT has been multifaceted but never far from the guiding hand of the ISI, and central to the low-intensity, proxy war waged by Pakistan's military to keep India off-balance and destabilised. At one level, LeT has been an independent actor capable of using trained Pakistani nationals executing guerrilla-style fedayeen attacks, first within Kashmir and then inside India proper against both civilian and military targets near the border. The assault on Delhi's iconic Red Fort in December 2000 by LeT-affiliated operatives was an early example of this species of terrorism (Tankel, 2011, pp. 65-66). It was dwarfed by the sea-borne assault by ten LeT gunmen on targets across Mumbai in November 2008, an operation in which the guiding hand of ISI control has been well established (Tankel, 2011, pp. 207-233).

LeT also played a key role in the training, in POK camps, of disaffected or suborned Indian Muslim citizens. These recruits, in many cases earlier members of SIMI, usually travelled covertly to Pakistan via the Gulf States or Iran (Sayed and Hakim, 2016, p. 158). Having undergone training in guerrilla fieldcraft and demolition and bomb-making techniques, they then returned to India by similar indirect routes, with no Pakistani visas in their passports. Their participation in terrorist attacks in India might follow months or even years later, on some occasions undertaken independently, and on others with assistance from Pakistani terrorists who had entered India covertly (frequently through Nepal) to provide support and guidance.

\section{International Terrorism}

To date, the 'internationalisation' of terrorism in India has occurred only insofar as Pakistan's military and the Pakistani jihadist groups it has supported have worked to exploit and exacerbate India's own religious and ethnic fissures. It is important to note that, up to the present, neither of the world's two most potent Islamist terrorist franchises, al-Qaeda (AQ) and so-called Islamic State (IS) have yet succeeded in gaining any serious traction among disaffected Indian Muslim youth. This, despite the fact that in September 2014, impelled by the rising fortunes of IS, AQ launched a jihadist franchise targeted specifically on South Asia and in particular India: al-Qaeda in the Indian Subcontinent (AQIS) (Roggio, 2014).

By comparison with other important regional AQ franchises, notably AQ in the Islamic Maghreb (AQIM) and AQ in the Arabian Peninsula (AQAP), AQIS has been strikingly ineffective inside India. The same to date has been 
true of IS. The IS call to join the struggle in Syria and Iraq has attracted a miniscule number of less than 100 Indian citizens from a Muslim population of 165 million (Sahni, 2016). In the cases of both AQIS and IS, Pakistan and Bangladesh have apparently proved more fertile ground for recruitment.

\section{Current Terrorism Threats to India}

\section{Nature of the threats today}

India's primary terrorist threat remains, as it has been since the turn of the century, the jihadist challenge. Over recent years this has evolved into an essentially three-pronged threat. One facet involves cross-border fedayeen-style attacks. Carried out by groups such as LeT and JeM which enjoy a close relationship with Pakistan's military establishment, these operations target security force installations along the international frontier and Line of Control (LOC), and indeed deeper inside Kashmir. Begun in the mid-1990s with LeT's strategy of fedayeen assaults in Kashmir, such attacks have been evident as recently as September 2016, when LeT operatives stormed an Indian Army base at Uri close to the LOC, killing 18 Indian soldiers; and in late November 2016, when another army base at Nagrota, near the state's summer capital of Jammu, was attacked.

A second prong consists of terror attacks, typically bombings, by disaffected Indian Muslim youth from groups such as IM, who enjoy not only connectivity with Pakistan but also training, logistical and, potentially, operational support. In both cases the potential for terrorist strikes raises a fundamental question which has deeply troubling implications for the security of the South Asian region as a whole, and to which the answer is far from clear: to what extent do Pakistan-based groups operate with the connivance and support of the ISI, and to what extent do they operate on their own initiative? In other words, is the Pakistani state in full control of its jihadi proxies? As noted by two American analysts in a recent article: 'If a new high-casualty terrorist attack occurs in India, especially in the heartland, a Modi government will be pressed to retaliate more dramatically than before. This, in turn, will put enormous pressure on Rawalpindi (i.e. Pakistan Army headquarters) to escalate in kind' (Dalton and Perkovich, 2017). The prescience of this observation became alarmingly clear in February 2019, when a Kashmiri youth, affiliated with JeM, carried out a suicide car-bomb attack on a convoy of Indian paramilitary troops on the main Jammu-Srinagar highway. The explosion killed 40 soldiers, the worst loss of life in any encounter in Kashmir to that date, and did indeed provoke retaliatory Indian air strikes on a suspected terrorist base at Balakot, beyond disputed Kashmir in the province of Khyber-Pakhtunkhwa. The strikes and the downing of an India fighter brought the two countries to the brink of wider conflict. 
A third and, to date at least, far less threatening prong of the jihadist menace is posed by disaffected Muslim self-starters inspired by IS's global call for attacks on targets of opportunity. What appeared to be the first instance of this threat surfaced in early March 2017, with an attack deploying a fairly crude, low-intensity, improvised explosive device (IED), in this case an ammonium nitrate-based pipe-bomb, on a train running between the cities of Bhopal and Ujjain in Madhya Pradesh state, which wounded ten people. According to police, the cell involved had been radicalised online by IS propaganda, it had acquired weapons and explosives locally, and had intended the train bombing as a trial run for more ambitious attacks. The cell was swiftly broken up after the attack, with the group's leader shot dead three days later during a police raid on a house in Lucknow, Uttar Pradesh, where a hand-painted IS-style flag was found. Six other suspects were later arrested in Madhya Pradesh (Jain et al., 2018). In notable contrast to other IS-linked attacks in the Subcontinent, such as the July 2016 café attack in Dhaka, Bangladesh, or the March 2017 attack on the military hospital in Kabul by IS-Khorasan militants, the train bombing passed entirely without mention from the IS media outlet Amaq, suggesting that there had been no connectivity between the cell and the IS parent organisation.

Given the reverses suffered by IS in the Middle East and the current difficulties of travelling to join the group, it is difficult to see the Ujjain train bombing as marking the beginning of a new wave of dispersed, IS-inspired terrorism in India. That said, over the medium to long term, ensuring the political and economic inclusion of India's Muslim minority will be a critical challenge for both central and state governments. This will be the case particularly in states run by the Hindu-nationalist BJP, a party with no shortage of inflammatory, Muslim-baiting politicians in its ranks. In the second term of Narendra Modi's BJP government, the prognosis is hardly encouraging.

\section{Residual Khalistan terror}

The Khalistan terror campaign of the 1980s and early 1990s was convincingly defeated. Nevertheless, Khalistan-inspired terrorism, fanned by elements both in Europe and in Pakistan, poses a perennial challenge, albeit a relatively minor one when set alongside that of jihadist terrorism. Arrests at various locations in August 2016 involved three operatives of the Khalistan Zindabad Force, allegedly under instructions from Khalistan exiles in the United Kingdom, Belgium and Pakistan, to assess prospects for reviving the movement and to carry out 'disruptive activities'. In November 2016, a Khalistan Liberation Force Leader, Harminder Singh Mintoo, was freed from a high-security facility at Nabha, Punjab in a dramatic jail break that revealed the connections between Khalistan terrorism and well-armed local organised crime. Harminder Singh, 
who in late 2014 had been extradited from Thailand, was re-arrested in Delhi the following day (New Indian Express, 2018). He died in jail in April 2018.

\section{Northeastern terrorism}

Equally, terrorism remains a persistent threat in Northeast India where multiple groups remain active, many of them riven by internal factional squabbles. The National Democratic Front of Bodoland is arguably the most vicious faction in terms of its targeting of civilians. Muslims and Adivasi tribal people, who arrived in Assam from Bihar and Jharkand states to work the tea plantations in the colonial era, have been the targets of choice. A December 2014 attack by NDFB gunman slaughtered 79 Adivasis across three districts. The massacre prompted a major Army response called Operation All Out, which reduced the NDFB considerably, while underscoring the extent to which in the Northeast counter-terrorism and counter-insurgency have become all but indistinguishable (India Today, 2014).

In addition to massacres and occasional bombings, Northeastern terrorism has been also been exacerbated by a relatively new cross-border threat, in the form of an alliance of ethnic factions based in ungoverned space in northwestern Myanmar (Burma). In April 2015, four factions - ULFA, NSCN-K, NDFB and the Kamtapur Liberation Organisation (KLO) - established the so-called United Liberation Front of West Southeast Asia (UNLF-WS). In the months following its creation, the umbrella grouping staged several cross-border attacks into Manipur and Nagaland, killing Indian security forces and prompting a June 2015 helicopter-borne raid by Indian commandos on two camps inside Myanmar (Davis, 2015). The emergence of the UNLF-WS marked the first time that such a broad alliance of disparate groups had been formally set up, and does not bode well for stability along India's far-flung northeastern border.

As the government in New Delhi has recognised for years, effectively reducing the terrorism and insurgent threat in the Northeast will hinge crucially on cooperation from Myanmar's military in denying the rebels cross-border sanctuary. As India has sought to expand economic and security ties with its eastern neighbour and to offset China's influence, achieving that cooperation has been a primary diplomatic goal. And in February 2019, tentative Myanmar military operations against a complex of insurgent camps at Taga in Sagaing Division suggested that progress had been made (Guwahati Times, 2019). However, Myanmar is still a long way from being able to make the sustained commitment of manpower and resources across its ungoverned northwestern marches that would be needed to root out Indian insurgent sanctuaries. 


\section{THE ARCHITECTURE OF INDIAN COUNTER-TERRORISM}

\section{Stakeholders in Indian Counter-Terrorism (CT)}

Given India's sheer size and federal structure a multiplicity of actors is involved, directly and indirectly in the counter-terrorism mission. These include, importantly, the following.

\section{Union government organisations and services}

\section{National Security Council (NSC)}

Established in 1998 and headed by the National Security Advisor, the NSC is the apex body advising the Prime Minister's Office on matters of national security and strategic interest including, importantly, terrorist threats. The heads of leading agencies tasked with counter-terrorism, notably the Intelligence Bureau, the Research and Analysis Wing and the National Technical Research Organisation, all answer directly to the National Security Advisor. In addition to the National Security Advisor and his deputy, the NSC - which meets on at least a monthly basis - also includes representatives of the ministers of Defence, Home Affairs, External Affairs and Finance.

\section{Strategic Policy Group}

The Strategic Policy Group serves effectively as the decision-making and operational nucleus of the NSC. It includes the heads of India's most important defence and security ministries, services and agencies, not least those tasked with the counter-terrorism.

\section{Joint Intelligence Committee (JIC)}

Part of the Secretariat of the National Security Council, the JIC is tasked with analysing intelligence data from the Intelligence Bureau, the Research and Analysis Wing, the Defence Intelligence Agency, and the Directorates of Military, Naval and Air Intelligence.

\section{National Security Advisory Board (NSAB)}

Composed of distinguished personalities from outside government, the National Security Advisory Board, which meets monthly, brings together a wide range of expertise in matters of security and defence. The body is intended to provide the NSC with 'big-picture' analysis of, and long-term recommendations for, security policy, almost certainly including policy on counter-terrorism. The NSAB has been criticised, however, as tending to 
reflect the ideological biases of the government of the day, and lacks direct access to key operational agencies.

\section{Intelligence Bureau (IB)}

Tracing its roots to the colonial period, the IB stands as the nodal agency for domestic counter-terrorism in India. Its Director (DIB) is the most senior police officer in the country, outranking all state-level police chiefs or heads of paramilitary Central Armed Police Forces. Always drawn from the cadre of the Indian Police Service (IPS), he answers directly to the Minister for Home Affairs. IB's Operations Wing represents the organisation's cutting edge, and is headed by a Director-General Operations (DG Ops). Deputies or 'Special Directors' are responsible for various aspects of internal security and major regions of the country. DG Ops and his deputies liaise with both IB's own bureaus at state level, as well as state-level police Anti-Terrorism Squads (ATS).

\section{Research and Analysis Wing (RAW)}

Set up in 1968 following intelligence failures surrounding the Sino-Indian border war of 1962, the RAW took over foreign intelligence collection and analysis which had earlier been the remit of the IB. As India's primary external intelligence service, its key responsibilities include the collection and analysis of intelligence on terrorist threats emanating from beyond the nation's borders. The RAW is headed by a Secretary (Research) in the Cabinet Secretariat, who answers to the Prime Minister and reports on a daily basis to the National Security Advisor. Two Special Secretaries and a number of Additional Secretaries are responsible for foreign intelligence processed through regional and country desks headed by Joint Secretaries. The RAW runs stations in Indian diplomatic missions in many countries, with a predictable emphasis on Asia, the Middle East and Africa.

\section{National Investigation Agency (NIA)}

Emerging directly from the intelligence weaknesses surrounding the Mumbai attacks of November 2008, the NIA was established later the same year with the passing by Parliament of the National Investigation Agency Bill. Unlike other point agencies involved in the CT mission, notably the IB and RAW, the NIA is dedicated exclusively to the terrorism threat, and is empowered to conduct investigations into terrorist incidents and conspiracies across India's states and union territories. Following an amendment to the National Investigation Agency Act (2008) it also conducts investigations into offences surrounding the smuggling of fake Indian currency into the country, which has been identified as a serious threat to India's monetary stability. The NIA does not, however, recruit or run its own intelligence assets. 
National Technical Research Organisation (NTRO)

Set up in 2004, the NTRO is India's pre-eminent technical intelligence-gathering agency. Answering to the National Security Adviser in the Prime Minister's Office, as of May 2017 the NTRO was listed by the Home Ministry as on a par with the RAW and IB under the Intelligence Organisations (Restrictions of Rights) Act of 1985. Described as a 'super-feeder' for technical intelligence to other agencies, the organisation's activities are centred on the technologically sophisticated realms of internet monitoring, telephone intercepts, cyber-security, cryptology and satellite surveillance.

\section{Aviation Research Centre (ARC)}

The ARC is part of India's external intelligence agency, the Research and Analysis Wing (RAW), and is tasked with aerial surveillance, photo reconnaissance, imagery intelligence (IMINT) and signals intelligence (SIGINT) along and across India's borders. Operating from several airbases around the country, the ARC's fleet of aircraft reportedly include Russian-built Ilyushin Il-76s and Antonov AN-32s as well as more modern Gulf Stream and Global 500 jets. The ARC was specifically commended by senior Air Force and Army officials for aerial imagery and surveillance found 'invaluable' in support of air strikes during the Kargil conflict of 1999. In recent years, however, the organisation is understood to have lost some of its functions to the NTRO.

\section{Defence Intelligence Agency (DIA)}

The DIA was established in 2002, following intelligence failings revealed by the 1999 Kargil war. Operating under the authority of the Ministry of Defence, the DIA is part of the tri-service Integrated Defence Staff. As its name indicates, the agency is focused on overtly military threats to India's security. However, the hybrid challenge posed by cross-border jihadist and insurgent attacks on India's northwestern and northeastern flanks that means the DIA is necessarily also focused on the terrorist threat and the gathering of intelligence aimed at countering it. Key elements of this mission are undertaken by the Indian Army's Directorate of Signals Intelligence and the Defence Image Processing and Analysis Centre (DIPAC), both of which are run by the DIA. The DIA is headed by a Director-General of three-star rank who is drawn in rotation from the three defence services and advises the Chief of the Integrated Defence Staff and the Minister of Defence. The DIA also liaises regularly with both the RAW and the IB, not least on CT issues.

\section{Directorate of Revenue Intelligence (DRI)}

Part of the Ministry of Finance, under the ministry's Central Board of Excise and Customs, the DRI is India's primary anti-smuggling intelligence and investigation agency, with a focus on firearms, gold, narcotics and fake Indian 
currency. To this extent it plays a potentially important role at the intersection of terrorism and transnational organised crime.

\section{Central Bureau of Investigation (CBI)}

Coming under the Ministry of Personnel, Public Grievances and Pensions, and headed by a Director-General of Police, the CBI is India's leading agency countering corruption, bribery, embezzlement and fraud. It plays a peripheral role in $\mathrm{CT}$ investigations.

\section{National Intelligence Grid (NATGRID)}

Emerging from the sweeping overhaul of intelligence and security agencies and procedures prompted by the 2008 Mumbai attacks, NATGRID is envisaged - but not yet fully operationalised - as an information-sharing network to facilitate the dissemination of data held by a range of central and state agencies, thereby promoting more effective cooperation within the Indian intelligence community. Coming under the Ministry of Home Affairs and initiated in 2011, it will eventually bring together 22 separate databases covering areas such as driving licences, passports, visa and immigration records, income tax, credit card transactions, and taxation and bank account details. NATGRID is not intended as a repository for operationally sensitive data.

\section{Paramilitary organisations}

\section{National Security Guard (NSG)}

Formed in 1984 under the authority of the Ministry of Home Affairs, the NSG provides the kinetic 'sharp end' of India's CT capability. While it is a leading armed counter-terrorist service, the NSG is not technically one of the Central Armed Police Forces (CAPF), however. The NSG's core anti-terrorist, anti-hijack capability is provided by two Special Action Groups whose personnel are seconded from the Indian Army. The police and CAPFs provide personnel for three Special Ranger Groups tasked with VIP protection, and so on. Following criticism of the NSG's slow response to the Mumbai terrorist attacks of November 2008, the force now deploys contingents in several major Indian cities. The National Bomb Data Centre tasked with monitoring, recording and analysing all bomb and IED incidents across India comes under the NSG.

\section{Central Reserve Police Force (CRPF)}

With a sanctioned strength of over 310000 personnel, the CRPF is the largest of India's Central Armed Police Forces. Under the authority of the Ministry of Home Affairs, it plays a leading role in supporting state police forces in maintaining civil order, as well as in counter-insurgency and counter-terrorist 
situations. Its lightly armed battalions have been widely deployed across all of India's zones of domestic conflict, most notably Kashmir, the Northeast and Maoist-affected areas of central India.

\section{Border Security Force (BSF)}

The BSF is the second-largest of India's Central Armed Police Forces and, as its name indicates, is deployed primarily in a border security role that has an obvious counter-terrorist dimension. BSF battalions have also frequently been deployed in internal security duties, not least in Kashmir. With an authorised strength of over 250000 it falls - like the CRPF - under the authority of the Ministry of Home Affairs, and is commanded by a Director-General drawn from the Indian Police Service (IPS). Given its front-line border role, the BSF is more heavily armed than the CRPF, and can deploy infantry support weaponry such as mortars and light artillery and some aviation assets. It also fields specialised commando units.

\section{Central Industrial Security Force (CISF)}

The CISF was established as one of India's Central Armed Police Forces by an Act of Parliament in 1983. Under the Ministry of Home Affairs, it has expanded significantly in recent years and today has a sanctioned strength of some 180000 personnel committed to the security of a wide range of government installations and critical infrastructure. All potentially at risk from terrorist attack, these include ports, airports, power plants, oil fields and refineries, atomic energy facilities and aerospace installations.

\section{Indo-Tibetan Border Police (ITBP)}

Raised in 1962 as a result of the border war with China, the ITBP was originally intended for deployment along the country's border with Chinese-ruled Tibet. However, its remit has been broadened to include border security and anti-smuggling in other parts of India, as well as a role in maintaining civil order, VIP protection and disaster response. One of the country's Central Armed Police Forces under the Home Affairs Ministry, the ITBP today has an authorised strength of around 90000 .

\section{Shashastra Seema Baal (SSB) or Armed Border Force}

The smallest of India's Central Armed Police Forces, with a strength of nearly 80000 personnel, the SSB emerged - like the ITBP - from the Indian defeat in the 1962 war with China as the Special Service Bureau. Established in 1963, it was envisaged as a 'stay-behind' force to mobilise the civilian population and conduct guerrilla warfare in the event of northern border areas being again overrun by Chinese invaders; as well as to provide support for the external intelligence service, the RAW. The SSB was reputed to have played 
an important role in 1971 in support of mukti bahini guerrillas in East Pakistan prior to the birth of Bangladesh. It has subsequently deployed in border areas across northern and northeastern India, notably along the $1751 \mathrm{~km}$ length of the Indo-Nepal border, an important zone of terrorist infiltration into India; and was involved in the 1999 Kargil theatre. The force has also been deployed in internal security and counter-insurgency roles in Maoist-affected states such as Bihar, Jharkand and Chhattisgarh.

\section{Railway Protection Force (RPF)}

With a strength of some 65000 personnel, the Railway Protection Force is a reflection of the size and economic importance of a railway network which is the world's third-largest and carries some 22 million passengers each day. Overseen by the Ministry of Railways, the Railway Protection Force is the only one of India's Central Armed Police Forces that does not fall under the authority of the Ministry of Home Affairs. It is also the only CAPF which has powers of arrest, investigation and prosecution. Its function is primarily to counter crime and anti-social behaviour, but given that the national railway network has been a perennial target of terrorist attack, the RPF also constitutes a link in the CT chain.

\section{State Government Organisations and Services}

\section{State Police Services and State Police Anti-Terrorism Squads (ATS)}

In liaison with the IB and RAW, state police forces, and specifically their Anti-Terrorism Squads, form the front-line in India's counter-terrorism campaign. State-level ATSs typically involve both an intelligence wing and a special weapons and tactics (SWAT) element. The pioneer in the development of a dedicated police CT wing was Maharashtra, of which Mumbai is the capital. While not all state police forces field an ATS, states that have found it necessary to adopt the same broad Maharashtra model include Gujarat, West Bengal, Uttar Pradesh, Rajasthan and Bihar.

\section{COUNTER-TERRORISM LEGISLATION AND THE LEGAL FRAMEWORK}

Given the virulence and scale of the terrorist threats it has faced in recent decades, along with the shortcomings of government agencies operating in strikingly different contexts, India has struggled to devise a comprehensive legal framework for its counter-terrorist response. Inherited from the British colonial era, India's default framework has been to deal with terrorist acts as criminal offences to be handled by state police forces. However, the nature of the threat has often spilled into protracted insurgency situations that have 
overwhelmed the capacity of state police and demanded the intervention of central paramilitary forces and the national military. These circumstances have resulted in the enactment, and in some cases the repeal, of several important legislative platforms drawn up specifically to meet the challenge of terrorism.

\section{The Terrorist and Disruptive Activities (Prevention) Act}

First promulgated in May 1985 and later amended in 1987, the Terrorist and Disruptive Activities (Prevention) Act, commonly known as TADA, was a direct response to the Khalistan terrorist campaign which swept Punjab in the second half of the 1980s and early 1990s. TADA was the first piece of legislation to provide a comprehensive definition of terrorism as seen by the Indian state. Coming in the Act's third paragraph, it is worth citing in full:

Whoever with intent to overawe the Government as by law established or to strike terror in the people or any section of the people or to adversely affect the harmony amongst different sections of the people does any act or thing by using bombs, dynamite or other explosive substances or inflammable substances or lethal weapons or poisons or noxious gases or other chemicals or by any other substances (whether biological or otherwise) of a hazardous nature in such a manner as to cause or as is likely to cause death of, or injuries to, any person or persons, or loss of or damage to, or destruction of, property or disruption of any supplies or services essential to the life of the community, or detains any person and threatens to kill or injure such person in order to compel the Government or any other person to do or abstain from doing any act, commits a terrorist act.

Against this backdrop, TADA extended sweeping powers to law enforcement agencies. These included the right to detain an accused individual for up to one year without formal charges; made confessions given to police officers of superintendent rank or above admissible evidence in courts of law; and reversed the presumption of innocence until proved guilty, with the burden of proof placed on the accused to establish their innocence. The Act also established special courts which allowed for trials to be held in closed court and for the identities of witnesses to remain secret. Further, it barred appeals from those accused to higher courts other than the Supreme Court. Predictably, given the scale of the Punjab crisis, once on the books TADA was widely used and abused. By June 1994, nine years after its promulgation, some 76000 individuals had been detained under its provisions. Of these cases only 35 per cent ever went to trial, and of those, convictions were secured in a mere 2 per cent of cases. Amid widespread allegations of abuse, the law was finally allowed to elapse in 1995 ('The Terrorist and Disruptive Activities (Prevention) Act', 1987). 


\section{Prevention of Terrorism Act (2002)}

Seven years after the discontinuation of TADA, the Indian parliament promulgated the Prevention of Terrorism Act (POTA) in March 2002. The passing of the new Act, which replaced the Prevention of Terrorism Ordinance of 2001, was driven by an increasing number of terrorist attacks, and in particular by the December 2001 assault on the Parliament building in New Delhi. It was nonetheless controversial from the outset, with the Parliament's Upper House (Rajya Sabha) voting it down and the bill passing only through a rare joint session that included the larger Lower House (Lok Sabha) (Economic Times, 2002). Like TADA, POTA rested, importantly, on several controversial clauses, notably that suspects could be detained for up to 180 days without charge; that law enforcement agencies were permitted to withhold the identities of witnesses; and that confessions made to police were admissible as evidence. At the same time the Act contained safeguards that had been absent from TADA. Importantly, it had no provisions permitting preventive detention; and appealing the verdict of the POTA Special Courts could be made to a division bench of the High Court.

As had been the case with TADA, there were soon renewed allegations of abuses of POTA legislation by state governments and law enforcement agencies. In particular these centred on the arbitrary harassment of political opponents. In December 2003, the Act was amended with an ordinance aimed at extending the scope of judicial review. A review committee which had earlier acted in a purely advisory capacity was strengthened, with review commissions armed with authority to issue orders binding on state governments and police. That said, the central review committee was still unable to initiate an investigation without an initial complaint by an 'aggrieved person'. In practice these were mostly individuals with political connections in central government, rather than terrorist suspects. POTA had been introduced by the National Democratic Alliance government. In October 2004, after approval in Cabinet, it was repealed by the centre-left United Progressive Alliance government.

\section{The Unlawful Activities (Prevention) Act}

Passed into law in December 1967, the Unlawful Activities (Prevention) Act (UAPA) was intended primarily to counter secessionist activities and associations threatening the sovereignty and territorial integrity of the Indian Union. Following several amendments, it has today become the primary plank of counter-terrorism legislation. UAPA had its roots in the recommendations of a Committee on national integration and regionalisation which in 1963 resulted in the Constitution (Sixteenth Amendment) Act. In the interests of national sovereignty, this empowered Parliament to impose reasonable restric- 
tions on freedom of speech and expression, the right of peaceful assembly and the right to form associations. UAPA was later introduced in Parliament to implement the provision of that Act.

Since it was passed into law in 1967, UAPA has been amended seven times (in 1969, 1972, 1986, 2004, 2008, 2012 and, most recently, in 2019). In the Unlawful Activities (Prevention) Amendment Act 2004, which followed the repeal of POTA, many of the provisions of the latter were re-incorporated in it. The Amendment Act (2008) which followed the November 2008 Mumbai attacks further strengthened the legislation. The Amendment Act (2012) was designed to meet commitments made at the inter-governmental Financial Action Task Force (FATF), aimed at combating money laundering and terrorist financing; while the Amendment Act (2019) was intended to facilitate the investigation and prosecution of terrorism-related crimes by the National Investigation Agency (NIA).

\section{Armed Forces Special Powers Acts}

With roots in colonial legislation aimed at countering the nationalist 'Quit India' movement of 1942, Armed Forces Special Powers Acts (AFSPA) are area-specific pieces of legislation contingent on any given area, usually along India's borders, being declared 'disturbed'. Such contingencies go well beyond a state government's declaration of a state of emergency. In state of emergency situations in which local police and administration are unable to fulfil their normal functions, the state government can call on the central government to provide paramilitary assistance, typically with the deployment of either the Central Reserve Police Force (CRPF) or the Border Security Force (BSF), or both. By contrast, AFSPAs imply the need to deploy regular armed forces 'in aid of the civil power' (under Article 246 of the Indian Constitution) in an area or entire state where the situation is deemed 'warlike' and which has been designated a 'disturbed area' by the central government.

Under an AFSPA in a 'disturbed area' the armed forces are accorded a range of powers covered by legal immunity from later prosecution. These include firing on persons after due warning; arresting persons without warrant (who must then be handed over to the officer in charge of the nearest police station with the least possible delay); entering and searching houses to make arrests; and stopping and searching vehicles and vessels suspected of transporting arms. To date, AFSPAs have been passed on three occasions. The first was the Armed Forces Special Powers (Assam and Manipur) Act 1958. The geographical scope of the Act, renamed the Armed Forces Special Powers Act 1958, was later extended to cover all seven states of the Northeast, although Tripura has since withdrawn, citing a marked improvement in the terrorist situation. The second was the Armed Forces (Punjab and Chandigarh) Special Powers Act 
1983, which gave legal sanction to army intervention in support of state police and central paramilitary forces countering the Khalistan campaign. The Act was withdrawn in 1997. The third occasion was the Armed Forces (Jammu and Kashmir) Special Powers Act 1990.

AFSPAs have been predictably controversial, with widespread allegations of 'faked encounters', and have invited sharp criticism both from the United Nations Human Rights Commission and international human rights organisations. Their extension (in six-monthly increments) for years at a stretch has also drawn criticism. In a landmark ruling in July 2016, the Supreme Court of India rescinded the AFSPA provision of immunity from prosecution for military personnel. The judgment noted that:

It does not matter whether the victim was a common person or a militant or a terrorist; nor does it matter whether the aggressor was a common person or the state. The law is the same for both and is equally applicable to both ... This is the requirement of a democracy and the requirement of preservation of the rule of law and the preservation of individual liberties. (Rajagopal, 2016)

It is worth noting that under AFSPA legislation approximately one-third of the Indian Army's manpower of 1.4 million active duty personnel is today committed to internal security duties; a situation over which senior echelons of the Army have made their unhappiness well known.

\section{COUNTER-TERRORISM TOOLS AND TACTICS}

The complex and variegated nature of the terrorist threat in India, and a federal Constitution which reserves policing and public order as state subjects, have effectively precluded the defining of any one overarching national counter-terrorism strategy. Indeed, following the Mumbai attacks of November 2008, the lack of any single agency with a nationwide remit exclusively tasked with coordinating counter-terrorism, became the focus of debate and controversy. The proposal to establish a National Counter-Terrorism Centre (NCTC) met stubborn opposition from state governments which viewed the nationwide intelligence-gathering and operational remit of such an agency as infringing on state powers. Effectively shelved in 2012, the NCTC concept appears since then to have died a natural death. The main institutional innovation emerging from the Mumbai debacle was the establishment of the National Investigation Agency (NIA), with its powers to conduct nationwide investigations into terrorist conspiracies.

As matters stand today, India's response to terrorism consists of a multi-pronged approach that, as its critics argue, continues to lack adequate coordination and cohesion. On the international stage, ratcheting up diplomatic 
pressure on Pakistan to desist from actively supporting terrorist organisations such as LeT and JeM has long been a central element of that overall approach. India has pushed its case against Pakistan in various fora such as the United Nations, the Group of Twenty (G20), the Shanghai Cooperation Organisation (SCO) and, not least, the Financial Action Task Force (FATF). The FATF in particular has continued to shine a harsh light on Pakistan's less than convincing efforts to crack down on terrorist financing. Domestically, improving the management of often porous borders by means of infrastructure as well as military and paramilitary patrolling has been defined as one element in the counter-terrorism mix. But arguably more important has been strengthening intelligence-gathering capabilities and coordination. The RAW externally, the IB domestically, and military agencies along and across borders, all play critical front-line roles supported by liaison and intelligence-sharing with foreign intelligence services.

Finally, and perhaps least noted, there have also been efforts to improve government and government-supported responses to the threat of radicalisation at local and community level. A multifaceted response marked by considerable regional variation, this essentially preventive prong of the counter-terrorism effort has involved modernisation of madrassahs, community policing initiatives, strengthening relations with local Muslim leaders and imams, and de-radicalisation programmes. In a country the size of India, its impact is almost impossible to gauge, but its importance should not be underestimated.

\section{REFERENCES}

'Annual Casualties in Jammu and Kashmir Datasheet' (2018), South Asia Terrorism Portal, accessed 25 July 2018 at https://www.satp.org/satporgtp/countries/india/ states/jandk/data_sheets/Fatalities_mha.htm.

'Annual Casualties in Punjab Datasheet' (2018), South Asia Terrorism Portal, accessed 16 July 2018 at https://www.satp.org/satporgtp/countries/india/states/punjab/data sheets/annual_casualties.htm.

BBC (2005), 'Gujarat Riot Death Toll Revealed', accessed 29 July 2018 at http://news .bbc.co.uk/2/hi/south_asia/4536199.stm.

Central Intelligence Āgency (1970), 'The Naxalites: India's Extreme Left-Wing Communists', Memorandum, accessed 18 July 2018 at https:/www.cia.gov/library/ readingroom/docs/CIA-RDP85T00875R001100090048-5.pdf.

Dalton, Toby and and George Perkovich (2017) 'Is a Pakistan-India War Just One Terrorist Attack Away?', Herald, accessed 15 August 2018 at https:// carnegieendowment.org/2017/01/24/is-pakistan-india-war-just-one-terrorist-attackaway-pub-67783.

Davis, Anthony (2000), ‘A New Kind of War', Asiaweek Magazine, 7 April.

Davis, Anthony (2015), 'India Launches Helicopter Borne Cross Border Raids', Jane's Terrorism and Insurgency Monitor, accessed at https://janes.ihs.com/ SecurityMonitor/Display/jtsm6415-jtsm-2015.

Economic Times (2002), 'President Summons Joint Sitting of Parliament', 22 March. 
Gill, K.P.S. (2001), Terror and Containment: Perspectives of India's Internal Security, Delhi: Gyan Publishing House.

Global News (2020), 'History of Air India Flight 182 Bombing', accessed at https:// globalnews.ca/video/6522826/history-of-air-india-flight-182-bombing.

Guwahati Times (2019), 'Myanmar Govt Acts Tough on NE Militant Outfits', accessed at https://guwahatitimes.com/myanmar-govt-acts-tough-on-ne-militant-outfits/.

Hindu (2016), 'Naxalism Biggest Threat to Internal Security: Manmohan', accessed 29 June 2018 at https://www.thehindu.com/news/national/Naxalism-biggest-threat-to -internal-security-Manmohan/article16302952.ece.

India Today (2014), 'After Assam Killings, All-Out War Begins against Bodo Militants', accessed at https://www.indiatoday.in/india/northeast/story/assam -killing-operation-all-out-army-bodo-militants-232851-2014-12-25.

'Indian Terrorist, Insurgent and Extremist Groups' (2018), South Asia Terrorism Portal, accessed 15 July 2018 at https://www.satp.org/terrorist-groups/india.

Jain, Bharti, Neeraj Chauhan, Karishma Kotwal and Pervez Iqbal Siddiqui (2018), 'Ujjain Train Blast Marks First IS Attack in India: 10 Injured 8 Arrested', Economic Times, accessed at https://economictimes.indiatimes.com/news/defence/ujjaintrain-blast-marks-first-is-attack-in-india-10-injured-8-arrested/articleshow/5753120 7.cms? from $=$ mdr.

Kiessling, Hein G. (2016), Faith, Unity, Discipline: The Inter-Service Intelligence (ISI) of Pakistan, London: Hurst \& Company.

'National Democratic Front of Bodoland (NDFB), Incidents and Statements involving NDFB: 2017, 2016, 2015, 2014, 2013, 1998-2012' (2018), South Asia Terrorism Portal, accessed 16 July 2018 at https://www.satp.org/satporgtp/countries/india/ states/assam/terrorist outfits/ndfb.htm.

New Indian Express (2018), 'Khalisani Liberation Force Chief Harminder Singh Mintoo Dies in Punjab Jail', accessed at https://www.newindianexpress.com/nation /2018/apr/18/khalistani-liberation-force-chief-harminder-singh-mintoo-dies-in-pun jab-jail-1803227.html.

Rajagopal, Krishnadas (2016), 'SC Ends Impunity for Armed Forces', Hindu, accessed 15 August 2018 at https://www.thehindu.com/news/national/SC-ends-impunity-for -armed-forces/article14478391.ece.

Roggio, Bill (2014), 'Al Qaeda in the Indian Subcontinent Incorporates Regional Jihadist Groups', Long War Journal, accessed 2 July 2018 at https://www.longwarjournal .org/archives/2014/09/analysis_al_qaeda_in.php.

Rukmini S. and Vijaita Singh (2017), 'Muslim Population Growth Slows', Hindu, 13 February, accessed 30 June 2018 at https://www.thehindu.com/news/national/ Muslim-population-growth-slows/article10336665.ece.

Sahni, Ajai (2016), 'Breaking News: IS Is Not Coming! IS Is Not Coming!' South Asia Terrorism Portal, accessed 4 July 2018 at https://www.satp.org/satporgtp/ajaisahni/ Breakingnews.htm.

Sayed, Nazia and Sharmeen Hakim (2016), Six Minutes of Terror, Gurugram, Haryana: Penguin Random House India.

Singh, Manoj K. and S.K. Chaudhary (2010), Maoist Guerrilla: Seeing Red, Delhi: Surendra Publications.

Singh, Prakash (1995), The Naxalite Movement in India, Kolkata: Rupa \& Co.

Tankel, Stephen (2011), Storming the World Stage, New York: Columbia University Press. 
'The Prevention of Terrorism Act (2002)' (2002), South Asia Terrorism Portal, accessed at https://www.satp.org/satporgtp/countries/india/document/actandordinances/PO TA.HTM.

'The Terrorist and Disruptive Activities (Prevention) Act (1987)' (1987), South Asia Terrorism Portal, accessed at https://www.satp.org/satporgtp/countries/india/ document/actandordinances/TADA.HTM.

'The Unlawful Activities (Prevention) Amendment Bill' (2019), LiveLaw.in, accessed at https://www.livelaw.in/pdf_upload/pdf_upload-362501.pdf.

Wilkinson, Steven I. (2006), Votes and Violence: Electoral Competition and Ethnic Riots in India, Cambridge: Cambridge University Press. 